Lutfiye Coskun ${ }^{1}$

Original scientific paper

Kilis 7 Aralık University

UDK: 37.018 .262

Kilis, Turkey

DOI: $10.5937 /$ IstrPed2102468C

\title{
MOTHERS' VIEWS AND HOME LITERACY PRACTICES ON CHILDREN LITERACY SKILLS ACQUISITION: A QUALITATIVE STUDY
}

\begin{abstract}
This study aimed to explore mother's views and home literacy practices for their children on literacy skills acquisition. In the study carried out in 2020, twenty-five mothers of children aged 6 years were assessed by means of a semistructured qualitative interview. Two mother views were identified; (1) family is responsible (FR) and (2) teacher is responsible (TR) on children's literacy skills acquisition. An examination of the literacy practices offered by mothers revealed that there are similarities and differences between the practices. The obtained results indicated that mothers who consider that family is responsible for children's literacy acquisition implemented more versatile and greater number of activities for their children. On the contrary, mothers who consider that teachers are responsible for children's literacy acquisition preferred mostly activities that support writing skills rather than reading skills. Some recommendations were also made in this paper to promote the emergent literacy skills of preschoolers.
\end{abstract}

Keywords: Emergent literacy skills, home literacy practices, mother views, preschoolers.

\section{Introduction}

The word literacy in the traditional sense means being able to read and write directly. However, with the concept of developing literacy, literacy skills refer to the informal processes that start from birth and continue until the beginning of traditional education. Knowledge, skills, and attitudes are considered the developmental premises of traditional literacy (National Research Council, 2001: 186). Similarly, while literacy skills are considered related to literacy that children acquire before formal literacy education according to Sulzby and Teale (1991), Whitehurst and Lonigan (1998) defined them as skills that contain the developmental premises necessary for learning traditional literacy.

From the emergent literacy perspective, literacy acquisition is not a spontaneous process starting with school, but a developmental process that emerges from the first years (Sandvik, van Daal, \& Ade`r, 2014). According to many scholars, waiting until children start primary school is not necessary to gain experiences in literacy. This means children could be supported in terms of literacy skills during the preschool period (Irwin, Moore, Tornatore, \& Fowler, 2012; Justice \& Ezell, 2001; Van Steensel, 2006).

Literacy skills, which are discussed in categories of oral language, print awareness, alphabet knowledge, and phonological sensitivity in the preschool period are important predictors of

${ }^{1}$ lutfiyeseven@hotmail.com 
children's reading success and development in later periods (Hammill, 2004; Welsh, Nix, Blair, Bierman, \& Nelson, 2010). Alphabet knowledge requires recognition of letters in the alphabet; print awareness is understanding written materials; oral language ability requires knowing the meaning of words; and phonological awareness requires skills to recognize the sounds in words (Dynia, Lawton, Logan, \& Justice, 2014). It is stated that the children who lacks these skills, fall behind their peers in terms of both social competence and academic success when they start primary school. This is because learning to read and write is related to children's past experiences; when children encounter a limited number of stimulants in an inadequate environment, their literacy skills are negatively affected in the long term (Lawhon \& Cobb, 2002).

Considering literacy skills separately from the sociocultural context is not a correct approach since these skills are based on a social understanding (Gee, 2001; Pellegrini, 2001; Wasik, Dobbins \& Herrmann, 2001). Emergent literacy refers to the emergence of literacy-related behaviors as a result of both social interaction and direct education. According to this view, the first priority is given to the social interaction for the emergence of literacy (OECD, 2006). Children's socializing experiences with their immediate surroundings directly affect how they learn literacy and spoken language (Pellegrini, 2001). Mothers and other caregivers play an important role in literacy development in infancy. Therefore, parents and caregivers should support their children's literacy development from the earliest years using appropriate means (Bus \& Van Ljzendoorn, 1997).

Many elements in the home environment such as child-adult relationships, availability of learning materials as well as physical conditions of the home affect the literacy development in children (Gonzalez \& Uhing, 2008). The home literacy environment in particular has an important impact on children's early literacy development (Buhs, Welch, Burt \& Knoche, 2011; Piasta, McGinty \& Kaderavek, 2012). Home literacy environment refers to an environment that parents create for their children at home, which is probably the most important contributor to preschool children's literacy learning (Manolitsis, Georgiou \& Tziraki, 2013; Niklas \& Schneider, 2013).

Home literacy environment promotes preschoolers' emergent literacy skills and their interest in literacy activities in two ways. The first one refers to the active participation of the mother or caregiver in literacy activities with the child. In the second scenario, the mother or caregiver becomes a role model for the child in literacy practices. For the second case, although the child is not actively participating in literacy activities, an environment where literacy is valuable and forefront is created by the mother or caregiver. Thus, in both cases, the mother or caregiver supports the literacy skill development of the child (Baroody \& Diamond, 2012). To put it simply, children's both observing and participating in home activities have a positive effect on their literacy development (Bennett, Weigel \& Martin, 2002; Leseman \& DeJong, 1998). In line with these findings, Teale and Sulzby (1986) defined three sources of home literacy environment that can contribute to preschoolers' emergent literacy skills. These are activities in which children interact with adults in writing and reading, independently explore writing, and gain experiences by observing an adult model who displays literacy behaviors (Stainthrop \& Hughes, 2000).

In studies examining home literacy environments, it was stated that a number of variables related to this environment such as parents' literacy habits, natural and official literacy activities between parents and children, shared book reading activities, and parents' beliefs about their children's literacy acquisition have a significant effect on children's emergent 
literacy development (DesJardin \& Ambrose, 2010; Gonzalez \& Uhing, 2008; Marjanovik Umek, Podlesek, \& Fekonja, 2005; McGinty \& Justice 2009; Taylor, 2011).

In a study conducted by Stephenson, Parrila, Georgiou, and Kirby (2008), it was found that parents' beliefs about their children's literacy achievements had an effect on their teaching activities at home, and these activities contribute to children's alphabet knowledge. Similarly, Weigel, Martin, and Bennett (2006) conducted a study examining the relationship between mothers' beliefs about the literacy acquisition of their children and the actual literacy development in children. Accordingly, they determined that there are two types of parentliteracy beliefs: traditional and supportive. The mothers with supportive views stated that home literacy education was important, whereas mothers with traditional views believed that the school is responsible for literacy development. The results obtained in another study showed that the beliefs and practices of the person who provides the care for children are effective on children's language and literacy skills (Foote, Smith, \& Ellis, 2004; Guimaraes \& Youngman, 1995; Newland et al., 2011).

Based on the above-mentioned reports, it can be argued that a relationship exists between parents' literacy beliefs and the quality of home literacy environments (Clingenpeel \& Pianta, 2007). In other words, parents' beliefs and expectations are effective on the literacy experiences they provide to their children (Sonnenschein et al., 1997). Moreover, some other studies also pointed out that rich home environments provided by parents where children can access written materials such as books and activities appropriate for their ages contribute positively to children's language and literacy skills (Raz \& Bryant, 1990). Also, both home literacy activities and learning resources within the home environment promote children's language and literacy skills (Purcell-Gates, 1996; Radisic \& Seva, 2013).

\section{Overview of the present study}

A literature survey revealed that many quantitative and qualitative studies were conducted examining teachers' (Lynch, 2009; Lynch, 2011; Sandvik, Van Daal \& Ader, 2014; Sverdlov, Aram \& Levin, 2014) and mothers' views and beliefs (Hammer, Rodriguez, Lawrence, \& Miccio, 2007; Lynch, Anderson, Anderson, \& Shapiro, 2006; Newland et al., 2011; Stephenson et al., 2008; Weigel, Martin \& Bennet, 2006) about literacy acquisition in children. However, only a limited number of qualitative studies have examined mothers' views and practices (Hammer \& Weiss, 2000; Sormunen, Goranskaya, Kirilina, Bykachev, \& Tossavainen, 2018). Therefore, more qualitative studies are needed to obtain in-depth information about parents' views and practices. Considering that the parents' literacy-related views have a significant effect on the literacy experiences they provide to their children, it is believed that the current paper will provide a valuable contribution to the preschool literature in terms of determining the mothers' views, the practices they have implemented with their children, and the materials they provided to their children. Furthermore, it is believed that the findings obtained in the present study will guide and provide valuable information to mothers of preschoolers regarding literacy practices. Also, examining mothers' views about implementing home literacy practices will help and make a valuable contribution to both early childhood educators and early childhood teacher education departments of universities.

Accordingly, the present paper aims at examining the views of mothers of preschoolers about their children's literacy acquisition, the literacy activities they implement at home, and the materials they provided. In this context, this study answered the following three research questions with a sample of Turkish mothers whose children were enrolled in a kindergarten: (1) What are the views of mothers of preschoolers about their children's acquisition of literacy 
skills?; (2) What kind of literacy activities do mothers implement for their children?; (3) What kind of literacy materials do mothers provide to their children? For each of these questions, we examined similarities and differences between FR and TR group mothers.

\section{Method}

\section{Procedures}

Qualitative semi-structured interviews were conducted with mothers of six-year-old children who had attended a kindergarten. Qualitative methods were chosen because these methods are particularly relevant for research questions about subjective perceptions of individuals and since the aim of this study is to complement the findings of other quantitative studies in this field. Semi-structured interviews lasted approximately 15 minutes. The main questions of the interviews are as follows: " 1 ) Who is responsible for your child's acquisition of literacy skills, what is your opinion? Please state your reason. 2) What activities do you implement to support your child's acquisition of literacy skills? 3) What materials do you use to support your child's acquisition of literacy skills?" The demographic information was collected regarding age, maternal education, child gender, and birth order. The educational level of mothers was rated using a four-point scale (elementary school, high school, bachelor, and graduate). Data were collected in the autumn of 2020 by the author of this paper. The permission to conduct this research was granted by the Scientific Research and Publication Ethics Committee of Kilis 7 Aralık University. The mothers were informed about the confidentiality of their answers to avoid socially desirable answers and to protect their privacy. Due to Covid-19 measures, survey data were collected electronically through online interviews. Responses were recorded by the interviewer in written notes.

\section{Participants}

A representative sample of mothers in Kilis, Turkey was included in the study. Two kindergartens were randomly selected from all those in Kilis province of Turkey. A researcher visited the schools, interviewed the kindergarten teacher, then five names from the register were randomly selected. It was intended to interview fifteen mothers from each school, but reserves were selected, also at random, in case of refusal. The interviewer reached the participants via the phone and asked if they were willing to answer questions about their children. All questions were open-ended and there were opportunities for further comment at the end of the interviews. A total of 25 mothers were interviewed about their children's literacy development. Interviews lasted approximately 15 minutes.

\section{Data analyses}

The qualitative data collected from the open-ended questions were examined using content analysis to obtain a framework of categories for mothers' responses. Content analysis, as defined by Graneheim and Lundman, is a systematic analysis technique for interview data. Categories were determined based on the data rather than fitting them into a theoretical framework (Creswell, 2012). We analyzed the transcripts of the interviews and reduced the data by converting them into developmental codes. The strategy was to begin with a broad outline and revise it. The data was narrowed down, and the following five categories emerged from the analyses of mothers' answers to the second question: writing skills, oral language skills, alphabet knowledge, math skills, and phonologic awareness. The same procedure was performed for the answers to the third question. The following five distinct categories 
emerged from the analyses of mothers' answers to the third question: writing materials, digital apps, reading materials, toys, and math materials.

The quotes from participants were presented in the tables. Since the participants gave more than one answer to the questions, the frequency ( $f$ ) numbers in the study group and categories differ. The participants' names were coded; mothers who consider that teacher is responsible in literacy education were coded as "TR" and mothers who consider that family is responsible in literacy education were coded as "FR".

\section{Results}

The results are given by categories and codes, supported by quotations from mothers.

\section{Participant characteristics}

We interviewed a total of 25 mothers of children who enrolling randomly selected two kindergartens. Demographic information of mothers and their children, frequencies, and percentages are given in Table 1 . Accordingly, $16 \%$ of the mothers participating in the study were in the age range of $20-29,60 \%$ in the age range of $30-39$, and $24 \%$ aged 40 years and older. As seen in Table 1, a majority of the participant mothers were high-school graduates.

Table 1. Demographic information of mothers and their children

\begin{tabular}{lll}
\hline Demographic information & $\mathbf{n}=\mathbf{2 5}$ & \\
\hline & & $\%$ \\
\hline Child's gender & 12 & 48 \\
\hline Female & 13 & 52 \\
\hline Male & 11 & 44 \\
\hline Birth order & 9 & 36 \\
\hline First child & 5 & 20 \\
\hline Second child & & \\
\hline Third and above & 4 & 16 \\
\hline Mother's age & 15 & 60 \\
\hline $20-29$ & 6 & 24 \\
\hline $30-39$ & & \\
\hline 40 and above & 4 & 12 \\
\hline Mother's education & 12 & 48 \\
\hline Primary school & 8 & 32 \\
\hline High-school & 1 & 4 \\
\hline Bachelor & & \\
\hline Graduate & & \\
\hline
\end{tabular}

\section{Results obtained from the first research question on mother views}

The mothers were asked, "Who is responsible for your child's acquisition of literacy skills, what is your opinion? Please state your reason." and the obtained results are presented in Table 2. As shown in the table, seven of the 25 mothers believe that "teacher is responsible in literacy education" (TR group mothers). On the other hand, the remaining eighteen mothers believe that "family is responsible in literacy education" (FR group mothers). Therefore, a majority of the mothers hold the view that the family is responsible for children's literacy acquisition.

Table 2. Findings regarding the mothers' views of literacy acquisition of their children View $\mathrm{n}(25)$ 
\begin{tabular}{ll}
\hline Family is responsible & 18
\end{tabular}

Teacher is responsible $\quad 7$

Some quotes from mothers' answers regarding their views of literacy skills acquisition are given below:

"I believe that teacher is responsible. Children should receive the literacy education first at school." (TR-2)

"Family is responsible because children learn new words and develop vocabulary knowledge before pre-school education." (FR-15)

"Family is important because children's education starts at family, the role of the family in children's education is essential." (FR-17)

"In my opinion, parents are obliged to ensure that their children receive pre-school education. And they should make pre-school activities and homework at home to support their child. However, it is not right for parents to give literacy education to their children." (TR-23)

"Teacher is responsible. If we educate our children, the presence of teachers and schools would become meaningless." (TR-25)

\section{Results obtained from the second research question on literacy activities}

The findings obtained from the second question of the study, "What kind of literacy activities do mothers implement for their children?" are shown in Table 3. Five categories were identified from the responses of the participants. These categories were as follows: Writing skills, oral language skills, alphabet knowledge, math skills, and phonologic awareness activities. Table 3 presents the categories and codes. Similarities and differences between the FR and TR group mothers were detailed for each research question.

Table 3. Literacy activities implemented by mothers to support their children's literacy skills

\begin{tabular}{|c|c|c|c|}
\hline Categories & Code & FR $(n=18)$ & $\operatorname{TR}(n=7)$ \\
\hline \multirow{4}{*}{ Writing skills } & Painting & 13 & 5 \\
\hline & Drawing & 10 & 1 \\
\hline & Playing play-dough & 9 & - \\
\hline & Line drawing & 5 & - \\
\hline \multirow{4}{*}{ Oral language skills } & Book reading & 17 & 4 \\
\hline & $\begin{array}{l}\text { Asking children to tell a } \\
\text { story }\end{array}$ & 4 & 1 \\
\hline & Teaching new words & 3 & 1 \\
\hline & $\begin{array}{l}\text { Finger games, riddle, } \\
\text { nursery rhyme }\end{array}$ & 3 & 2 \\
\hline \multirow{2}{*}{ Alphabet knowledge } & Letter writing & 10 & 4 \\
\hline & Word writing & 8 & 2 \\
\hline \multirow[b]{2}{*}{ Math skills } & Teaching numbers & 12 & 4 \\
\hline & $\begin{array}{c}\text { Drawing geometric } \\
\text { shapes }\end{array}$ & 3 & - \\
\hline Phonologic awareness & Teaching phonics & 3 & - \\
\hline None & - & - & 2 \\
\hline
\end{tabular}

The results indicated that the most frequently implemented activities are writing skills, oral language skills, and alphabet knowledge, respectively. As seen in Table 3, the mothers implemented a total of 13 different activities. While all of these 13 different activities were implemented by FR group mothers, TR group mothers implemented only 9 of these activities. Furthermore, while all FR group mothers conducted at least one of these activities, two TR group mothers did not implement any literacy activities for their children. 
It was found that book reading activity was implemented by twenty-one mothers (17 FR and 4 TR). Furthermore, according to the findings, the book reading activity was the most common activity performed by the mothers in both groups compared to other activities. While 3 FR group mothers implemented phonics teaching activities, none of the TR group mothers implemented these activities. Fourteen mothers (10 FR and 4 TR) implemented word teaching activities. Moreover, sixteen mothers (4 FR and 12 TR) implemented activities about teaching numbers. Accordingly, these findings imply that mothers from both groups attach importance to word teaching and number teaching activities. Among FR group mothers, 9 mothers implemented playing play-dough activity, 5 mothers implemented line drawing activity, and 3 mothers implemented teaching phonics activities. However, none of the TR group mothers implemented such activities.

Some quotes from mothers' comments regarding activities they implemented are as follows:

"To be honest, I couldn't implement such activities. Because I live in difficult conditions and therefore, I don't have enough time to do activities with my children and I couldn't spend time with them." (TR-3)

"I did not implement activities, but I taught them to count." (TR-5)

"We create various activities to spend time with my child. We sing songs, we create nursery rhymes, we constantly communicate. We buy fairy-tale books and go to the cinema." (FR-7)

"In fact, I don't do many activities, but I give my kid play-dough to promote his/her finger muscles. My child plays play-dough." (FR-12)

"I taught my child English and Turkish alphabets. I taught my child to hold a pencil." (FR-24)

\section{Results obtained from the third research question on literacy materials}

The results from the third question of the study, "What kind of literacy materials do mothers provide their children?" are shown in Table 4. Five categories were identified from the answers of the participants. These categories were as follows: writing materials, digital apps, reading materials, toys, and math materials. The identified codes and corresponding categories are listed in Table 4. Similarities and differences between the FR and TR mothers were detailed for each research question.

Table 4. Materials provided by mothers to support the literacy skills of their children

\begin{tabular}{llll}
\hline Categories & Code & FR $(\mathbf{n}=\mathbf{1 8})$ & TR $(\mathbf{n}=\mathbf{7})$ \\
\hline \multirow{3}{*}{ Writing materials } & Coloring books & 13 & 5 \\
& Notebook-pencil & 12 & 4 \\
& Writing board & 4 & 1 \\
\hline \multirow{2}{*}{ Digital apps } & Smartphone apps & 13 & 3 \\
& Tablet apps & 4 & 1 \\
\hline \multirow{2}{*}{ Reading materials } & Computer apps & 7 & - \\
\hline \multirow{2}{*}{ Toys } & Story books & 17 & 5 \\
& Alphabet books & 5 & - \\
\hline \multirow{2}{*}{ Math materials } & Educational toys & 4 & 2 \\
& Intelligence toys & 3 & - \\
\hline None & Puzzles and Blocks & 4 & - \\
\hline
\end{tabular}


The results indicated that the most frequently used literacy materials by mothers were writing materials, digital apps, and reading materials, respectively. As seen in Table 4, mothers provided a total of 12 different materials to their children. While all these 12 materials were provided by FR group mothers, TR group mothers used only 7 of 12 materials. Furthermore, all FR group mothers provided at least one of these materials whereas, two mothers in the TR group did not provide any literacy materials to their children. According to Table 4, while FR group mothers provided educational toys, intelligence toys, puzzles, and Blocks to their children, TR group mothers did not provide any of such materials to their children. Some quotes from mothers' comments regarding the materials they provided to their children are given below:

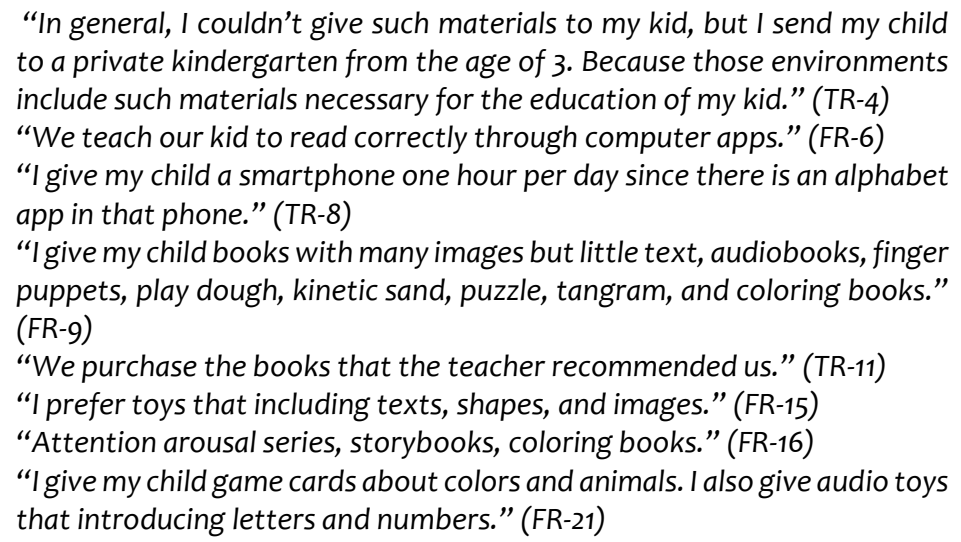

\section{Discussion and Conclusion}

This study used semi-structured interviews to explore and identify mother's views and home literacy practices about young children's acquisition of literacy skills. It was determined that mothers who participated in this study had different views regarding the literacy acquisition of their children and a majority of them held the opinion that the family is responsible for literacy acquisition of children. It can be argued that mothers consider family as the first teacher of children and have some background regarding the importance of children's literacy acquisition. Similarly, Sonnenschein et al. (1997) found that parents' beliefs regarding the literacy acquisition of their children are affected by their cultural background and past experiences.

We found that mothers who believe that family is responsible for children's literacy acquisition (FR mothers) conducted a more versatile and greater number of activities to facilitate literacy acquisition compared to other mothers (TR mothers). For example, while FR group mothers implemented playing play-dough, teaching phonics, line drawing, and drawing geometric shapes activities, none of the mothers who believe that teacher is responsible for literacy acquisition of children (TR group mothers) conducted such activities. This finding indicates that mothers' views have an impact on whether they will play an active or passive role in their children's literacy acquisition process. Consistent with our findings, DesJardin and Ambrose (2010) determined that parents who play an active role in their children's literacy acquisition conducted divergent literacy activities such as playing language games, singing songs, regular library visits, and daily reading activities. Furthermore, Weigel, Martin and Bennett (2006) found that mothers who believe that they have an important role in the literacy acquisition of their children offered a home environment rich with language and literacy activities. 
The obtained results revealed that mothers from both groups focused on mostly book-reading activities. Therefore, it can be argued that mothers are aware of the importance of book reading. However, how mothers conducted this activity and the targeted literacy skill is unknown. Book reading activity includes various reading types. Previous studies pointed out that reading with attention to print promotes a child's print awareness and alphabet knowledge and accordingly, the importance of reading with attention to print was highlighted (Justice \& Ezell, 2001). Therefore, although a majority of the mothers implemented book reading activities with their children, they should be informed about the benefits of shared book reading to support their children's print awareness. For example, a study conducted by Gordon Elias, Ross, and Kate (2006) showed that children of parents who participated in book reading training displayed higher emergent literacy skills. Furthermore, Frijters, Barron and Brunello (2000) found that the frequency of shared book reading activity is an important predictor of children's emergent literacy skills such as alphabet knowledge and phonological awareness.

Although a majority of the mothers conducted activities regarding oral language skills and writing skills, fewer mothers implemented phonological awareness-related activities. While three FR group mothers conducted teaching phonics activities, none of the TR group mothers implemented teaching phonics-related activities. Developing phonological awareness in preschool aged children is very essential for emergent literacy skills. To learn reading, a child should be aware that words are made up of different sounds. This skill is called phonological awareness and is a powerful predictor of children's further literacy skills. Many studies reported the significant impact of phonological awareness in children's literacy acquisition (Lonigan, Burgess, \& Anthony, 2000; Overby et al., 2012; Pinto, Bigozzi, Gamannossi, \& Vezzani, 2012). However, considering the fact that only 3 (FR) of 25 mothers conducted phonological awareness-related activities, it can be argued that most mothers do not have enough information about the activities promoting children's phonological awareness. To support the development of phonological awareness in preschool aged children, providing some training to mothers should be considered.

Furthermore, it was determined that while a majority of the mothers implemented similar activities such as book reading, teaching letters, drawing, they never conducted literacyrelated unique activities. However, examining different written materials such as newspapers, magazines, encyclopedias, and atlas; hanging notes on boards and refrigerators, making library visits, increasing the variety of written materials at home, and parents' reading for themselves are some of the tasks that parents should implement for their children's literacy acquisition (Stainthrop \& Hughes, 2000; Weinberger, 1996). Consequently, it was determined that the mothers did not practice versatile literacy activities. This result suggests that mothers are not informed by teachers about literacy activities they can implement.

Mothers from both groups conducted more letter teaching activities compared to other activities. That finding indicates mothers focused on formal activities rather than natural and daily activities. Consistent with these findings, Shaw (2007), Altiparmak (2010), Kilic and Erturk Kara (2019) determined that parents implemented formal activities like teaching letters more than natural activities such as reading and playing games. However, considering the item related to the emergent literacy activities included in the Turkish 2013 Preschool Education Program saying "Teaching reading and writing are not included in the program. Also, there is no showing and printing letters", it seems that families should be informed about not implementing letter teaching activities to their children. Teachers may implement seminars or meetings about the scope and curriculums' of preschool for mothers to better understand the 
scope and goals of the preschool education. The main point in the children's literacy acquisition process is that involving them in natural literacy activities. For example, some of the daily activities that parents can do with their children to support emergent literacy development are singing rhyme songs, cutting, and pasting old catalogs, preparing birthday cards, writing on a foggy window, creating a shopping list, writing letters, and writing recipes (Makin \& Whitehead, 2004; Weinberger, 1996).

Moreover, some mothers implemented math activities such as teaching numbers and geometric shapes which are not directly related to the children's literacy acquisition. Additionally, FR group mothers implemented more versatile and greater number of literacyrelated activities than those in the TR group. Obviously, mothers' views are effective in their decisions regarding activities and materials provided to their children.

While all FR group mothers provided at least one literacy material, none of the TR group mothers provided literacy materials to their children. Gershoff, Aber, Raver and Lennon (2007) found that literacy materials provided to children by their parents positively affect the cognitive and language development of children. Therefore, it can be argued that if mothers are informed regarding the importance of versatile literacy materials on child development, they will provide a variety of literacy materials and attach more importance. Furthermore, it was found that mothers used appropriate materials for the age of their children. According to Hart and Risley (1992), using appropriate materials for the age of children promotes establishing a parent-child relationship. Moreover, a majority of participating mothers gave storybooks to their children as home literacy materials. Considering these findings, it can be argued that mothers attach importance to using storybooks. According to Evans, Shaw, and Bell (2000), parents have an important role in increasing the number of home reading materials by either purchasing or renting books from libraries; thus, they can promote their children's literacy development by giving them appropriate books.

Many studies indicated that the home literacy activities performed by parents have a positive impact on their children's literacy skills (Eva, Lau \& Nirmala, 2011; Foy \& Mann, 2003; Law, 2008; Martini \& Senechal, 2012; Newland et al., 2011; Schmit, Simpson, \& Friend, 2011; Weigel, Martin, \& Bennett, 2010). Therefore, parents should be informed about the home literacy activities by researchers, educators, and teachers. If parents are well-informed and develop awareness, they will implement versatile and effective activities.

Finally, preschoolers gain emergent literacy experience at home through activities before they start formal education. Parents' awareness and beliefs are effective in the selection and implementation of proper literacy practices. The obtained results in the present paper revealed that mothers who consider that family is responsible for children's literacy acquisition implemented more literacy activities and gave more versatile materials to their children compared to mothers who consider that teacher is responsible for literacy acquisition. All these results suggest that there is an important link between the views and practices of mothers.

\section{Limitations and Recommendations}

This study has some methodological limitations that require comments. First, the results are limited to mothers' self-reports of home literacy activities. Limitations due to self-report data could have contributed to the relationship between mothers' literacy views and home literacy practices. Observations of mothers' literacy activities might provide more accurate determinations about the relationship between mothers' literacy views and activities. Also, this study had some limitations of using qualitative research methods. Further studies designed 
with quantitative and mixed research methods can be carried out. The sample of this study consisted of mothers of children attending a preschool. More studies can be conducted with mothers of children of different age groups and their views and practices can be compared. Another limitation of this study is that it is not known how much time mothers engage in these activities and how often they perform these activities.

The following recommendations can be made to institutions, curriculum designers, and teachers to better support mothers with valuable information about the importance of the home literacy environment. Accordingly, parents could play a more active role in their children's literacy acquisition. First, training programs can be designed for mothers to inform them about literacy acquisition and activities; thus, mothers could provide versatile materials and a greater number of activities for their children. Mothers might be informed about activities related to daily life rather than formal ones. It was determined that participant mothers implemented more writing skills-related activities than reading-related activities. Only fewer mothers implemented phonological awareness-related activities, which is an important literacy skill. Therefore, mothers should be informed about implementing a greater number of reading activities.

In the present study, two main variables related to the home literacy environment were examined; literacy activities implemented, and literacy materials provided to children by mothers. However, some other variables related to home literacy environment such as mothers' reading habits, reading frequencies, and reading experiences were not investigated. Furthermore, this paper tried to examine mothers' views regarding their children's literacy skills. Further studies may examine mothers' own reading habits and beliefs. Additionally, further studies can be conducted to determine the relationship between different variables related to home literacy environment and parents' practices and beliefs regarding the literacy acquisition of their children.

\section{References:}

Altıparmak, S. (2010). Parental perceptions on emergent literacy in early childhood years. Master's thesis, Middle East Technical University, Institute of Social Sciences, Ankara.

Baroody, A. E., \& Diamond, K. E. (2012). Links among home literacy environment, literacy interest, and emergent literacy skills in preschoolers at risk for reading difficulties. Topics in Early Childhood Special Education, 32(2), 78-87.

Bennett, K. K., Weigel, D. J., \& Martin, S. S. (2002). Children's acquisition of early literacy skills: Examining family contributions. Early Childhood Research Quarterly, 17, 295-317.

Buhs, E. S., Welch, G., Burt, J., \& Knoche, L. (2011). Family engagement in literacy activities: revised factor structure for The Familia an instrument examining family support for early literacy development. Early Child Development and Care, 181(7), 989-1006.

Bus, A. G., \& Van ljzendoorn, M. H. (1997). Affective dimension of mother-infant picture book reading. Journal of School Psychology, 35(1), 47-60.

Christensen, L. B., Johnson, R. B., \& Turner, L. A. (2015). Research methods, Design and analysis. Pearson.

Clingenpeel, B. T., \& Pianta, R. C. (2007). Mother's sensitivity and book-reading interactions with first graders. Early Education and Development, 18(1), 1-22.

Creswell, J. (2012). Educational research: Planning, conducting, and evaluating quantitative and qualitative research (4th edn). New Jersey: Pearson. 
DesJardin, J. L., \& Ambrose, S. E. (2010). The importance of the home literacy environment for developing literacy skills in young children who are deaf or hard of hearing. Exceptional Children, 13, 28-44.

Dynia, J. M., Lawton, K., Logan, J. A. R., \& Justice, L.M. (2014). Comparing emergent-literacy skills and home-literacy environment of children with autism and their peers. Topics in Early Childhood Special Education, 34(3) 142-153.

Eva, Y. H., Lau, H. L., \& Nirmala, R. (2011). Parental involvement and children's readiness for school in China. Educational Research, 53(1), 95-113

Evans, M. A., Shaw, D., \& Bell, M. (2000). Home literacy activities and their influence on early literacy skills. Canadian Journal of Experimental Psychology, 54, 65-75.

Foote, L., Smith, J., \& Ellis, F. (2004) The impact of teachers' beliefs on the literacy experiences of young children: A New Zealand perspective. Early Years, 24,135-147.

Foy, J. G., \& Mann, V. (2003). Home literacy environment and phonological awareness in preschool children: Differential effects for rhyme and phoneme awareness. Applied Psycholinguistics, 24, 59-88.

Frijters, J. C., Barron, R. W., \& Brunello, M. (2000). Direct and mediated influences of home literacy and literacy interest on prereaders' oral vocabulary and early written language skill. Journal of Educational Psychology, 92, 466-477.

Gee, J. P. (2001). A sociocultural perspective on early literacy acquisition. In S. Neuman \& D. Dickerson (Ed.s). Handbook of early literacy development (pp. 30-42). New York: Guilford.

Gershoff, E., Aber, J., Raver, C., \& Lennon, M. (2007). Income is not enough: Incorporating material hardship into models of income association with parenting and child development. Child Development, 78(1), 70-95.

Gonzalez, J. E., \& Uhing, B. M. (2008). Home literacy environments and young Hispanic children's English and Spanish oral language. Journal of Early Intervention, 30(2), 116139.

Gordon Elias, I. H., Ross H., \& Kate F. (2006). Enhancing parent-child book reading in a disadvantaged community. The Australian Journal of Early Childhood, 31, 20-25.

Graneheim, U. H., \& Lundman, B. (2004). Qualitative content analysis in nursing research: Concepts, procedures and measures to achieve trustworthiness. Nurse Education Today, 24(2), 105-112.

Guimaraes A. S., \& Youngman, M. (1995). Portuguese preschool teachers' beliefs about early literacy development. Journal of Research in Reading 18, 39-52.

Hart, B., \& Risley, T. R. (1992). American parenting of language-learning children: Persisting differences in family-child interactions observed in natural home environments. Developmental Psychology, 28, 1096-1105.

Hammer C. S., \& Weiss A. L. (2000). African American mothers' views about their infants' language development. American Journal of Speech Language Pathology, 9, 126-140.

Hammer, C. S., Rodriguez, B. L., Lawrence, F. R., \& Miccio, A. W. (2007). Puerto Rican mothers' beliefs and home literacy practices. Language, Speech, and Hearing Services in Schools, $38,216-224$.

Hammill, D. D. (2004). What we know about correlates of reading. Exceptional Children, 70, 453468.

Irwin, J. R., Moore, D. L., Tornatore, L. A., \& Fowler, A. E. (2012). Expanding on early literacy promoting emerging language and literacy during storytime. Children and Libraries, Summer/Fall, 20-24.

Justice, L. M., \& Ezell, H. K. (2001). Word and print awareness in 4-year-old children. Child Language Teaching and Therapy, 17, 207-225. 
Kilic, Ş., \& Erturk Kara, H. G. (2019). The Relationship between Parents' Practices on Early Literacy and Children's Word and Print Awareness Skills. Erzincan University Journal of Education Faculty, 22(1), 35-50.

Law, Y. K. (2008). The relationship between extrinsic motivation, home literacy, classroom instructional practices, and reading proficiency in second-grade Chinese children. Research in Education, 80, 37-51.

Lawhon, T., \& Cobb, J. B. (2002). Routines that build emergent literacy skills in infants, toddlers, and preschoolers. Early Childhood Education Journal, 30(2), 113-118.

Leseman, P. P. M., \& DeJong, P. F. (1998). Home literacy: Opportunity, instruction, cooperation and social-emotional quality predicting early reading achievement. Reading Research Quarterly, 33, 294-318.

Lonigan, C. J., Burgess, S. R., \& Anthony, J. L. (2000). Development of emergent literacy and early reading skills in preschool children: Evidence from a latent-variable longitudinal study. Developmental Psychology, 36, 596-613.

Lynch, J., Anderson, J., Anderson, A., \& Shapiro, J. (2006). Parents' beliefs about young children's literacy development and parents' literacy behaviours. Reading Psychology, 27, 1-20.

Lynch, J. (2009). Preschool teachers' beliefs about children's print literacy development. Early Years: An International Research Journal, 29 (2), 191- 203.

Lynch, J. (2011). An observational study of print literacy in Canadian preschool classrooms. Early Childhood Educational Journal, 38, 329-338.

Makin, L., \& Whitehead, M. (2004). How to Develop Children's Early Literacy (A Guide For Professional Carers and Educators. Paul Chapman Publishing; London.

Manolitsis, G., Georgiou, G. K., \& Tziraki, N. (2013). Examining the effects of home literacy and numeracy environment on early reading and math acquisition. Early Childhood Research Quarterly, 28(4), 692-703.

Marjanovik Umek, L., Podlesek, A., \& Fekonja, U. (2005). Assessing the home literacy environment relationships to child language comprehension and expression. European Journal of Psychological Assessment, 21(4), 271-281.

Martini, F., \& Senechal, M. (2012). Learning literacy skills at home: Parent teaching, expectations, and child interest. Canadian Journal of Behavioral Science, 44(3), 210-221.

McGinty, A.S., \& Justice, L. M. (2009). Predictors of print knowledge in children with specific language impairment: Experiential and developmental factors. Journal of Speech, Language, and Hearing Research, 52, 81-97.

National Research Council. (2001). Eager to Learn: Educating our Preschoolers. Washington, DC: National Academy Press.

The Ministry of National Education (MONE) (2013). Turkish 2013 Preschool Education Program. Ankara: MONE Printing House.

Newland, L. A., Gapp, S. C., Jacobs, G. M., Reisetter, M. F., Cambetas, D., \& Wu, H. (2011). Mothers' beliefs and involvement: Links with preschool literacy development. International Journal of Psychology, 9, 67-90.

Niklas, F., \& Schneider, W. (2013). Home literacy environment and the beginning of reading and spelling. Contemporary Educational Psychology, 38(1), 40-50.

OECD (Organization for Economic Cooperation and Development) (2006). Starting Strong II: Early Childhood Education and Care. Paris: OECD.

Overby, M. S., Trainin, G. Smit, E. B., Bernthal, J. E., \& Nelson, R. (2012). Preliteracy speech sound production skill and later literacy outcomes: A study using the templin archive. Language, Speech, and Hearing Services in Schools, 43, 97-115.

Pellegrini, A. D. (2001). Some theoretical and methodological considerations in studying literacy in social context. In S. Neuman \& D. Dickerson (Ed.). Handbook of early literacy development (pp. 54-65). New York: Guilford. 
Piasta, S. B., Justice, L. M., McGinty, A. S., \& Kaderavek, J. N. (2012). Increasing young children's contact with print during shared reading: Longitudinal effects on literacy achievement. Child Development, 83(3), 810-82.

Pinto, G., Bigozzi, G., Gamannossi, B. A., \& Vezzani, C. (2012). Emergent literacy and early writing skills. The Journal of Genetic Psychology, 173(3), 330-354.

Purcell-Gates, V. (1996). Stories, coupons, and the TV guide: Relationships between home literacy experiences and emergent literacy knowledge. Reading Research Quarterly, 31, 406-428.

Radisic, J., \& Seva, N. (2013). Exploring the factor structure of the parent reading belief inventory (PRBI): example of Serbia. Psihologija, 46(3), 315-330.

Raz, I., \& Bryant, P. (1990) Social background, phonological awareness and children's reading. British Journal of Developmental Psychology, 8, 209-225.

Saban, A. I., \& Altınkamış, N. F. (2014). An investigation of literacy beliefs of pre-school children's parents. Journal of Human Sciences, 11(1), 317-337.

Sandvik, J. M. van Daal, V., \& Ade`r, H. J. (2014). Emergent literacy: Preschool teachers' beliefs and practices. Journal of Early Childhood Literacy 14(1), 28-52.

Schmitt, S. A., Simpson, A. M., \& Friend, M. (2011). A longitudinal assessment of the home literacy environment and early language. Infant and Child Development, 20, 409-431.

Shaw, D. (2007). Home literacy activities as means of parental support for children's reading development. Doctoral Dissertation, The University of Guelph, Ontario.

Sonnenschein, S., Baker, L., Serpell, R., Scher, D., Goddard Truitt, V., \& Munsterman, K. (1997). Parental beliefs about ways to help children learn to read: The impact of an entertainment or a skills perspective. Early Child Development and Care, 127(1), 111-118.

Sormunen, M., Goranskaya, S., Kirilina, V., Bykachev, K., \& Tossavainen, K. (2018). Home and school responsibilities for children's health literacy development: the views of Finnish and Russian parents and teachers. Russian Journal of Communication, 10(1), 70-90.

Stainthrop, R., \& Hughes, D. (2000). Family literacy activities in the homes of successful young readers. Journal of Research in Reading, 23, 41-54.

Stephenson, K. A., Parrila, R. K., Georgiou, G. K., \& Kirby, J. R. (2008). Parents' beliefs, and children's task-focused behaviour on emergent literacy and word reading skills. Scientific Studies of Reading, 12(1), 24-50.

Sulzby, E., \& Teale, W. H. (1991). "Emergent literacy: New perspectives" in emergent literacy: Young children to read and write. International Reading Association.

Sverdlov, A., Aram, D., \& Levin, I. (2014). Kindergarten teachers' literacy beliefs and selfreported practices: On the heels of a new national literacy curriculum. Teaching and Teacher Education, 39, 44-55.

Taylor, J. J. (2011). Paternal support of emergent literacy development: Latino fathers and their children. The International Honor Society in Psychology, 16(2), 58-72.

Teale, W. H., \& Sulzby, E. (1986). Emergent literacy as a perspective for examining how young children become writers and readers. In W. H. Teale and E. Sulzby (Eds.) Emergent literacy: Writing and reading. Norwood, NJ: Ablex.

Van Steensel, R. (2006). Relations between socio-cultural factors, the home literacy environment and children's literacy development in the first years of primary education. Journal of Research in Reading, 29(4), 367-382.

Wasik, B. H., Dobbins, D. R., \& Herrmann, S. (2001). Intergenerational family literacy: Concepts, research, and practice. In S. Neuman \& D. Dickerson (Ed.s). Handbook of early literacy development (pp. 444-458). New York: Guilford.

Weigel, D. J., Martin S. S., \& Bennett, K. K. (2006). Mothers' literacy beliefs: Connections with the home literacy environment and pre-school children's literacy development. Journal of Early Childhood Literacy, 6(2), 191-211. 
Weigel, D. J., Martin, S. S., \& Bennett, K. K. (2010). Pathways to literacy: Connections between family assets and preschool children's emergent literacy skills. Journal of Early Childhood Research, 8(1), 5-22.

Welsh, J. A., Nix, R. L., Blair, C., Bierman, K. L., \& Nelson, K. E. (2010). The development of cognitive skills and gains in academic school readiness for children from low-income families. Journal of Educational Psychology, 102, 43-53.

Weinberger, J. (1996). Literacy goes to school. London: Paul Chapman.

Whitehurst, G., \& Lonigan, C. (1998). Child development and emergent literacy. Child Development, 69, 848-872.

\section{Biographical notes:}

Lütfiye Coşkun is an assistant professor doctor in the Department of Early Childhood Education at Kilis 7 Aralık University, Turkey. She completed her bachelor's degree in preschool education at İnönü University, Faculty of Education in 2007, master degree in preschool education at Inönü University in 2011 and PhD degree in preschool education at Gazi University in 2016. She has been at North Texas University as visiting scholar in 2015. Her research interests include preschool education, literacy skills in early childhood, on reading books to children. 